\title{
ASPECTE DE CERCETARE FITOHELMINTOLOGICĂ ȘI FITOPATOLOGICĂ LA CULTURA DE ARDEI GRAS (CAPSICUM ANNUM L.) ÎN TEREN PROTEJAT
}

\author{
Bivol Alexei1, ${ }^{1}$, Toderaș lon ${ }^{1}$, lurcu-Străistaru Elena ${ }^{1}$, Bădărău Sergiư², \\ Rusu Ștefan'1, Sasanelli Nicola ${ }^{3}$ \\ ${ }^{1}$ Institutul de Zoologie al Ministerului Educației, Culturii și Cercetării, Chișinău, R. Moldova \\ 2Universitatea Agrară de Stat din Moldova, or. Chișinău \\ 3/nstitutul de Protecție a Plantelor (IPP), secția Nematologie, sectorul Bari, Italia \\ E-mail: iurcuelena@mail.ru
}

https://doi.org/10.53937/9789975315975.31

În perioada anilor 2013 - 2018 în Republica Moldova legumicultura a avansat semnificativ în teren protejat la producerea fructelor de ardei, cu o producție 130 mii tone anual și fiind de două ori mai avansată, comparativ cu perioada anilor 2006 - 2012 (60 mii tone). Anual, circa 70 mii tone sunt procesate la uzinele industrial alementare din țară, iar mai bine de 80 mii tone se expediază spre comercializare, în stare proaspătă, pe piețile interne și externe. Cultivarea intensivă a ardeiului pe teren protejat este o îndeletnicire tradiţională, cu caracter regional și are avantaje agroeconomice și comerciale, în vederea asigurării eșalonate pe tot parcursul anului a producţiei de fructe proaspete. Se dezvoltă intensiv această direcţie legumicolă în asociaţii de producere, sectoare individuale private, modernizate cu utilaj eficient de cultivare, bazate pe mecanizarea și automatizarea procedeelor ajustate în condiţii de sere încălzite și solarii. Dintre cele mai semnificative culturi legumicole, ardeiul gras ocupă un loc valoros în topul speciilor de legume, cu avantaje agrobiologice, economice, alimentare și curative.

Clima caldă, solurile fertile corespund valorificării acestei culturi în plan dirijat, dar acest fapt creează condiții favorabile în apariția și evoluția asociaţiilor de agenți fitopatogeni și complexe de nematode fitoparazite, ce provoacă fitohelmintoze și maladii fitopatogene cu impact major 
ce compromit grav producția de ardei gras în condiții de teren protejat. Investigaţiile au fost realizate în 5 raioane din diverse zone ecologo-geografice, specializate în cultivarea legumelor în teren protejat, unde s-au colectat peste 100 de probe de sol și plante afectate, pentru analize ulterioare în laborator. Evidenţe fitosanitare s-au efectuat prin sondaje de rută în diferite gospodării legumicole de ardei cu sortiment variat din sere, solarii în diverse asociații de producție, gospodării ţărănești, sectoare private. S-a constatat tipul și calitatea solului, cultura premergătoare, starea fitosanitară, cu determinarea gradului de infestare și intensitatea afecțiunilor fitopatogene, fitohelmintice. În condiţii de laborator s-a determinat densitatea efectivului numeric, structura complexelor de fitonematode la cultura de ardei gras cu stabilirea apartenenței taxonomice și spectrului de specializare trofică conform indicilor bioecologici.

Reeșind din actualitatea temei abordate, scop și obiective propuse s-a efectuat monitoringul fitosanitar la ardeiul gras din teren protejat, în elucidarea impactului fitoparazitar helmintologic și fitopatologic, în stabilirea nematofaunei, asociate cu maladiile specifice la ardei, cu scop de determinare a gradului de afecțiune, componență etiologică a maladiilor cheie, pentru recomandarea unor procedee de protecție ecologică.

S-au efectuat sondaje de evidență fitosanitară, cu prelevarea probelor de sol și plante de ardei afectate, în asociațiile de producție legumicole cu complexe de sere din raioanele: Anenii-Noi, Criuleni, laloveni, Orhei și Soroca, cu suprafețe de peste 10 ha de ardei și echipate cu tehnologii de dirijare a cultivării.

În rezultatul cercetărilor fitosanitare și analizelor de laborator, s-a stabilit diagnosticul epidemiologic și impactul fitohelmintologic și fitopatologic la plantele de ardei și estimată structura complexelor de fitonematode parazite, care fiind constituită din 28 specii de fitonematode cu o densitate medie de $380-760$ indivizi $/ 100 \mathrm{~cm}^{3} / \mathrm{sol}$. Gradul de infestare fitohelmintică la plante în faza formării fructelor, varia în limitele de la 5 până la 40\%, persistând asociaţiile de fitonematode invazive, cu efec- 
te fitoparazitare specifice din genurile: Meloidogyne, Pratylenchus, Paratylenchus, Helicotylenchus, Rotylenchus, Ditylenchus, Bitylenchus, Tylencorhynchus. Dominante, fiind asociaţiile de fitonematode cu specializare trofică ecto-semi-endo parazitare $30-40 \%$, comparativ cu formele libere, iar din speciile daunătoare mai frecvent s-au remarcat următoarele specii de fitohelmintoze specifice: Meloidogyne incognita, M. hapla, M. arenaria, Tylenchus filiformis, Ditylenchus dipsaci, D. destructor, Helicotylenchus digonicus, Pratylenchus pratensis, P. penetrans, Tylenchorynchus dubious, Nothotylenchus acris.

S-a stabilit gradul de intensitate și frecvenţă a maladiilor asociate la cultura ardeiului gras prin

evidențierea dinamicii creșterii plantelor, începând cu faza de răsad până la recoltare: maladia piciorușului negru provocat de un complex agresiv de agenţi patogeni (Pythium sp., Rhiyoctonia solani, Alternaria sp., Botrytis cinerea, Fusarium sp., Pinicillium sp., Aspergillus sp., Mucor sp., Rhizopus sp.), urmate de ofilirea fuzariană (Fusarium oxysporum Schl. Var. capsicum), alternarioza (Alternaria porri f. solani), stolburul micoplasmatic (Chlorogenus austaliensis), mozaicul comun (Nicotiana virus 1), în valori de la 25-50\% al gradului de dăunare pe frunze și fructe.

Rezultatele monitoringului fitosanitar realizat, servesc la elucidarea gradului de dăunare fitohelmintică și fitopatologică, în scop de pronosticare și argumentare a măsurilor de protecție predestinate agrocenozelor legumicole de ardei gras în teren protejat.

Investigațiile au fost realizate în cadrul proiectului 15.817.02.12F, finanțat de Consilul Supărem pentru Știință și Dezvoltare Tehnologică al Academiei de Stiințe a Moldovei și a proiectului STCU-6233 din cadrul Programului direcţiei strategice Iniţiative Comune de Cercetare - Dezvoltare, cu cifrul 17.80013.5107.12/6233, pentru anul 2018 nr.289 din 15.12.2017. 